(2018), 1 (1): 32-35

\title{
ENHANCING THE FIRST SEMESTER STUDENTS' SPEAKING ABILITY USING INSTRUCTIONAL VIDEO
}

\author{
Sri Fatmaning Hartatik \\ IKIP Budi Utomo \\ fatmaninghartatik@gmail.com \\ Ike Dian P. \\ IKIP Budi Utomo \\ dyanike3@gmail.com
}

\begin{abstract}
This one-cycle Clasroom Action Research (CAR) was intended to improve students' speaking abilty in describing someone. This was done because the researchers' observation during preliminary study showed that students found difficulties in delivering their thought in speaking. It was indicated by their hesitation to present their thoughts. Besides, from some students' performance during preliminary study, the researchers found that students still found difficuties to pronounce English words. To this, instructional video implementation was selected to eliminate this problem. After the plannings were implemented, the results of video implementation was reflected by reflecting the revealed scores with the criteria of success. Finally, it was found that using instructional video in teaching speaking did not only improve students' speaking ability but also motivate students to participate actively in the teaching and learning process.
\end{abstract}

Keywords: instructional video, speaking skill

CPendidikan Bahasa Inggris FPISH IKIP BU Malang

\section{Introduction}

As English has been widely used as a means of communication in this digital era, the demand of employees who have mastered this language is increasing. Therefore, today's teaching and learning English as a Foreign language is focused on developing learners communicative competence; it is learners' ability to use the language to communicate, both in spoken and written modes. Amongst the four language skills, one's ability to use the language in speaking is one of the most noticable indicators that they have successfully learned the target language. Unfortunately, there are still many studies reported that EFL learners still find difficulties in delivering their thoughts in spoken mode. Riswandi (2016) found that students in his class had several communication problems, they are low learning motivation and interest; could not fluently express their ideas by using appropriate vocabulary and correct grammatical forms; and the atmosphere of the class did not support any speaking activity. As the consequences, the students were reluctant and unmotivated to speak. In addition, Hidayat \& Kurniawati (2018) highlight that the majority of English learners in Indonesia cannot speak fluently because their pronunciation is low. This also happened to the first semester students of English Department taking Basic Speaking Class. From the preliminary study, it was figured out that students felt unconfident when they were to speak in front of the class. They admitted that pronunciation is one of more dominant problems which 
hinderred them from speaking English. In addition, their limited knowledge on English vocabulary and grammar also became their reasons why they felt insecure when they were speaking in English.

Based on the result of preliminary, the researchers then decided to solve the students' problem by using video to increase students ability to speak in Englih. The selection of video implementation as a solution to this particular problem was based on several studies which proved the effectiveness of video in teaching English. In addition, empirical studies indicated students' improvement in learning English also became the basis of this particular study.

\section{Research Method}

As this study aimed at enhanching students' ability to speak in English, the design of this study was Classroom Action Research (CAR). According to Latief (2009), CAR is designed to solve teaching and learning problem. In its implementation, this study involved 25 five students taking Basic Speaking class at English Department of IKIP Budi Utomo Malang. As it was mentioned in the introduction, these sudents found difficulties in speaking because they had limited knowledge on English vocabulary, pronunciation, and grammar. This made them feel unconfident when they were requested to speak in front of the class. To solve this problem, one-cycle Classroom Action research was carried out. This cycle covered conducting preliminary study, planning, acting, observing and reflecting. In performing preliminary study, the researchers observed the students' performance during teaching and learning process. To confirm their observation, the researchers interviewed the students in group. After the results of the priliminary study was found, the researchers, then, were planning the action. In planning the action, the researchers reviewed some previous studies which had similar topic and concern. Next, the researchers constructed a lesson plan before selecting teaching materials. After that, the researchers determined the minimum passing grade which was 70 ; this minimum passing grade was determined in accordance to the English Department passing grade. The next step was video implementation. During the implementation, the researchers observed the students' attitude as the qualitative data of this study. Next, after the implementation was accomplished, the researcher then assigned the students' to describe their favorite idol. During their speaking performance, the researchers evaluated the students performance by using scoring rubric. The results of inter raters score were reflected by comparing average scores with the minimum passing grade.

\section{Findings and Discussion a Quantitative Findings}

After inter raters scoring was done, finally it was found that students' achievement in speaking, especially describing idol in spoken manner, increased. This was indicated by the percentage of the students who passed the minimum passing grade; they were 91\% students who passed minimum passing grade. Table 1 is the summary of the students' score

Tabel 1 Students' Speaking Scores

\begin{tabular}{llll}
\hline NO & STUDENTS & SCORES & CRITERIA \\
\hline 1 & N & 80 & Very Good \\
\hline 2 & DA & 84 & Very Good \\
\hline 3 & AR & 76 & Good \\
\hline 4 & MBT & 68 & Poor \\
\hline 5 & NH & 86 & Excellent \\
\hline 6 & W & 70 & Good \\
\hline 7 & MA & 76 & Good \\
\hline
\end{tabular}




\begin{tabular}{llll}
\hline 8 & MWG & 76 & Good \\
\hline 9 & PW & 80 & Very Good \\
\hline 10 & ML & 80 & Very Good \\
\hline 11 & ID & 86 & Very Good \\
\hline 12 & DLNF & 88 & Excellent \\
\hline 13 & RA & 74 & Good \\
\hline 14 & KH & 88 & Excellent \\
\hline 15 & SB & 72 & Good \\
\hline 16 & AB & 74 & Good \\
\hline 17 & SU & 82 & Very Good \\
\hline 18 & DG & 76 & Good \\
\hline 19 & YS & 86 & Very good \\
\hline 20 & RTB & 72 & Good \\
\hline 21 & STI & 90 & Excellent \\
\hline 22 & EI & 84 & Very Good \\
\hline & Average & 79,45 & Very Good \\
\hline
\end{tabular}

\section{b. Qualitative Findings}

In addition to quantitative findings, which are demonstrated by students' score, this research also revealed qualitative findings. These qualitative findings were reflected by students' behavior during the video implementation. Besides, to get students' deeper opinion on the video implementation, the researcher proposed some questions in group interview section. The results of observation showed that students looked enthusiastic when they were watching the modelling video. In addition, they also looked more confident when they presented their thought about their idols. When the results of observations confirmed in interview section, the researcher believed the video had given positive impact on students' speaking performance. This was supported by RTB who said "ternyata dalam berbicara memang tidak selalu menggunakan tata bahasa yang baku, kita bahkan bisa bertanya tanpa harus menggunakan pattern yes no atau wh questions..." (it is true that in speaking, sometimes, we do not always use grammatical sentences, even we can ask questions without yes no or wh question patterns...". Different from RBT, NH stated that "Dengan menonton video kita jadi tahu cara mengucapkan kosa kata bahasa Inggris, kalau di buku kan kadang-kadang kita hanya mengira ngira saja bagaimana cara pelafalannya." (by watching the video, we know how to pronounce some English vocabulary; when we read the vocabulary on text book we just randomly guess how to say the words..)

\section{c. Discussion}

Referring to the findings of this study, the researchers suggested that the implication of instruction video was effective to enhance students' speaking skill by improving students' confidence and interest in the teaching and learning process. The positive gains in those aspect is in line with the study conducted by Riswandi (2016) which concluded that the nature of video, which provides picture and audio at the same time, is able to help the students train their pronunciation, enrich their vocabulary, and make them easier to find an idea in producing sentences while speaking. The students can get information faster and feel more confident in dealing with the lesson as they not only depend on their speaking skills but also on their comprehension. In addition, watching videos also unconsciously help the students learn grammar in an automatic way. Saleng et.al. (2014) also found that using instructional video in learning could improve students' speaking skill because this medium is interesting. Through video learning, the students got fun and enjoyable learning. In addition, the students were motivated in this way. Morover, Bajrami \& Ismaili (2016) generated that students find the experience of using video material to be interesting, relevant, beneficial and somewhat motivating in class. 


\section{Conclusion and suggestion}

From the quantitative findings and qualitative findings above, we can conclude that an instructional video plays an important role as a teaching medium as well as learning source as it could enhance students' speaking skill as well as students' motivation in Speaking class. This is so because videos presented authentic language so that learner can learn directly how English is used in spoken manner. Besides, a modelling video does not only improve students' speaking skill but also foster students' positive attitude toward speaking activities. This is so because video can attract both those with auditory learning styles as well as visual learning style so that language learners will be more attracted to get involved in the classroom teaching and learning process.

Based on the conclusion mentioned previously, the researchers would like to make suggestion for several parties. First for any language teachers who might face similar problems in teaching speaking, they are suggested to use instructional videos to help their learners to improve their speaking ability. Next suggestion was made for further researchers. This research was only limited to improve the first semester students' speaking ability, to broaden empirical findings dealing with the use of instructional video, further researchers are encouraged to conduct similar topic with different subject and setting. They are also expected to use instructional video in teaching different skills in order to provide wider insights on the use of instructional videos in teaching English problems of teaching English Pronunciation in Indonesia. Proceedings of International Conference on the Future of Education (IConFEd) 2018, Institute of Teacher Education Tuanku Bainun Campus, Penang, Malaysia, 10-12 July 2018. Retrieved on August $2^{\text {nd }} 2018$ from

www.ipgktb.edu.my/iconfed/.../B I/.../B28_Wahyu\%20Hidayat\%20 \%20et\%20al.pdf

Latief, M.A. 2009. Classroom Action Research in Language Learning. Malang: UM Press.

Riswandi, D. 2016. Use of YouTubebased Videos to Improve Students' Speaking Skill. (Online) Proceeding the $2^{\text {nd }}$ International Conference on Teacher Training and Education Sebelas Maret University, Vol.2 No.1, Retrieved on August $23^{\text {rd }}$ 2018 from https://jurnal.uns.ac.id/ictte/articl e/view/8150

Saleng, M., Manurung, K., \& Darmawan. 2014. The Implementation of Video Learning to Improve Speaking Ability. (Online) e-journal of English Language Teaching Society (ELTS) Vol. 2 No 3. Retrieved on August $25^{\text {th }} 2018$ from http://jurnal.untad.ac.id/jurnal/ind ex.php/ELTS/article/view/3050

\section{References}

Hidayat, W. \& Kurniawati, Y. 2018. The language teaching challenge: The 